\title{
Development of early mouse and rabbit embryos without zona pellucida
}

\author{
O. J. Rottmann and W. W. Lampeter*
}

Lehrstuhl für Tierzucht der Technischen Universität München, 8050 Freising-Weihenstephan, and ${ }^{*}$ Lehrstuhl für Tierzucht der Ludwig-Maximilian Universität München, Veterinärstrasse 13, West Germany

\begin{abstract}
Summary. Criteria for assessing embryo vitality of denuded rabbit and mouse embryos in vitro were: volume of the embryo, number of cells and number of metaphase plates after 24 and $48 \mathrm{~h}$ in culture. Mouse embryos grew normally, with and without the zona pellucida, but denuded rabbit embryos showed reduced growth (volume and cell number) and failure to implant in synchronized recipients.
\end{abstract}

\section{Introduction}

The development of early embryos has frequently been studied and for embryo manipulations it is necessary to know the importance of the zona pellucida and the viablity of the embryo without its zona. Mouse embryos have mainly been studied (Tarkowski, 1959; Mintz, 1962; Moustafa, Hahn \& Roselius, 1978; Konwinski, Solter \& Koprowski, 1978) and mouse embryos can implant and develop successfully without the zona pellucida (Mintz, 1962). However, the criteria available for assessing the vitality of embryos for in-vitro investigations are few (Konwinski et al., 1978) and in the present study we have used the volume, number of cells and number of metaphase plates at a given time of development to assess the viability of embryos of various species.

\section{Materials and Methods}

Animals. Virgin, female NMRI mice, about 60 days old, were induced to superovulate with 1.5 i.u. PMSG (Anteron: Schering) injected intraperitoneally. They were mated $48 \mathrm{~h}$ later and 2 i.u. hCG (Primogonyl: Schering) were injected. The day the vaginal plug was found was considered to be Day 1 of pregnancy. On Day 3, the mice were killed and the embryos were flushed from the uteri with phosphate-buffered saline $(\mathrm{pH} 7 \cdot 2)$ supplemented with $5 \%$ fetal calf serum.

The New Zealand White rabbits were virgins and induced to superovulate with 60 i.u. PMSG i.m. They were artificially inseminated $72 \mathrm{~h}$ later, ovulation being induced by intravenous injection of 60 i.u. hCG (Day 0). The does were killed on Day 3 and the morulae were flushed from the oviduct with BSM II (Maurer, 1978).

Treatment of embryos. Removal of the mucin coat and zona pellucida from the eggs was accomplished by treatment with pronase (Boehringer: 1\% in BSM II). Removal of the layers took up to $3 \mathrm{~min}$ and was facilitated by drawing the embryos in and out of a fine Pasteur pipette and by tearing the zonae. Immediately after removal of the zona pellucida, the embryos were washed twice in BSM II and placed singly into small culture dishes filled with BSM II supplemented with bicarbonate $(2106 \mathrm{~g} / \mathrm{l})$, glucose $(1800 \mathrm{~g} / \mathrm{l})$ and $20 \%(\mathrm{v} / \mathrm{v})$ fetal calf serum. 
The embryos were incubated in an humified atmosphere of $5 \% \mathrm{CO}_{2}$ in air at $37.5^{\circ} \mathrm{C}$ for 24 or $48 \mathrm{~h}$. Photographs of each denuded and control embryo were taken at the start of incubation and after 24 and $48 \mathrm{~h}$. After incubation, colcemid was added to the culture medium and $4 \mathrm{~h}$ later chromosome preparations were made of all eggs by the method of Tarkowski (1966). The following data were obtained: embryo volume (calculated from the diameter of the cell mass) at 0,24 and $48 \mathrm{~h}$ of incubation, number of cells after 24 and $48 \mathrm{~h}$ and the number of metaphase plates.

Transfer studies. In synchronized recipient rabbits laparotomy was performed under anaesthesia induced by pentobarbitone sodium and maintained with ether. The uterine horns and ovaries were exposed via a mid-line incision. Transfer pipettes were thin glass tubes connected to a $1 \mathrm{ml}$ syringe. The bore of the pipette was such that the volume of medium used, up to 0.05 $\mathrm{ml}$, occupied a $3 \mathrm{~cm}$ column. Zygotes were transferred into the upper part of the oviduct via the infundibulum immediately after being flushed from the donor. When morulae were being transferred, the uterine wall was punctured by a blunt steel needle about $1 \mathrm{~cm}$ from the utero-tubal junction, care being taken to avoid blood vessels. With the transfer pipette aimed towards the cervix, it was then introduced into the lumen to a depth of $2 \mathrm{~cm}$. The fluid containing the morulae was expelled by gentle pressure on the plunger with the pipette being simultaneously withdrawn. Aseptic techniques were used in all procedures.

Statistical procedure. The data were analysed using the SPSS-program (Nie \& Hull, 1975). The following hypothesis was tested: independence of the development with and without zona pellucida concerning the criteria volume, cell number and number of metaphase plates. The means, standard deviations and regression analyses were also obtained by the SPSS-program.

\section{Results}

Development of the control embryos

Data from 191 rabbit and 163 mouse control embryos allowed to grow under defined, reproducible culture conditions are given in Table 1 . The low standard deviations at $0 \mathrm{~h}$ indicate that there had been little growth of the blastomeres by this time. The volume of the embryo increased within the next 24 and $48 \mathrm{~h}$ (PI. 1, Figs 2 and 4).

Table 1. Dimensions of control rabbit $(\mathrm{N}=191)$ and mouse $(\mathrm{N}=163)$ embryos after 0,24 and $48 \mathrm{~h}$ in culture

\begin{tabular}{lccc}
\hline & \multicolumn{3}{c}{ Incubation time } \\
\cline { 2 - 4 } & $0 \mathrm{~h}$ & $24 \mathrm{~h}$ & $48 \mathrm{~h}$ \\
\hline $\begin{array}{l}\text { Rabbit } \\
\text { Diameter (mm) } \\
\begin{array}{l}\text { Embryo volume } \\
\quad \text { Mean } \pm \text { s.d. }\end{array}\end{array}$ & 0.111 & 0.147 & 0.305 \\
$\begin{array}{l}\text { Mouse } \\
\quad \text { Diameter (mm) } \\
\text { Embryo volume }\left(\times 10^{-4} \mathrm{~mm}^{3}\right) \\
\quad \text { Mean } \pm \text { s.d. }\end{array}$ & $7.2 \pm 2.5$ & $16.6 \pm 11.4$ & $148.5 \pm 15.8$ \\
\hline
\end{tabular}

\section{PLATE 1}

Fig. 1. A denuded rabbit embryo after $24 \mathrm{~h}$ in culture.

Fig. 2. Control rabbit embryo after $24 \mathrm{~h}$ in culture. Note the difference of size of control and denuded (Fig. 1) embryos.

Fig. 3. A denuded mouse embryo after $24 \mathrm{~h}$ in culture.

Fig. 4. Control mouse embryo after $24 \mathrm{~h}$ in culture. Note the similar sizes of control and denuded (Fig. 3) embryos. 
PLATE 1
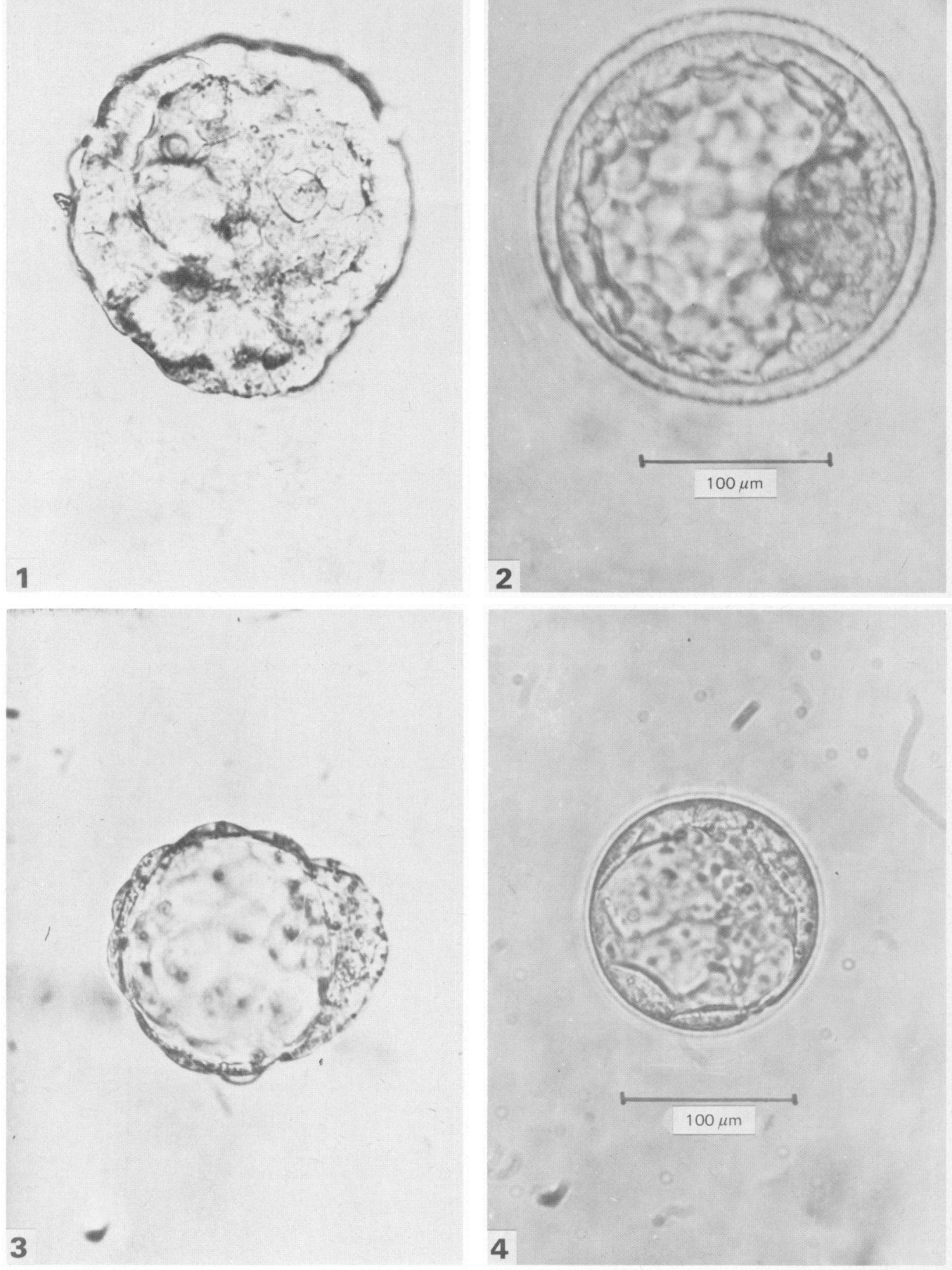

(Facing p. 304) 
Development of denuded embryos in vitro

The denuded rabbit embryos grew more slowly than did the control embryos. Mouse embryos were unaffected (Table 2). Immediately after removal of the zona pellucida the volume of the denuded embryos was larger than that of the control embryos, probably because of a loosening of the blastomere formation, but after 24 and $48 \mathrm{~h}$ the volume of the denuded rabbit embryos and the number of cells were less than that in controls. The mitotic index was not affected.

Table 2. Development of rabbit and mouse embryos in vitro

\begin{tabular}{|c|c|c|c|c|c|}
\hline \multirow[b]{2}{*}{$\begin{array}{l}\text { Incubation } \\
\text { time (h) }\end{array}$} & & \multicolumn{2}{|c|}{ Rabbit } & \multicolumn{2}{|c|}{ Mouse } \\
\hline & & $\begin{array}{c}\text { Control } \\
(\mathrm{N}=191)\end{array}$ & $\begin{array}{c}\text { Denuded } \\
(N=177)\end{array}$ & $\begin{array}{c}\text { Control } \\
(\mathrm{N}=163)\end{array}$ & $\begin{array}{c}\text { Denuded } \\
(N=159)\end{array}$ \\
\hline 0 & Volume $†$ & $47 \cdot 8 \pm 4 \cdot 6$ & $68 \cdot 0 \pm 4 \cdot 6^{* *}$ & $32.3 \pm 2.7$ & $34.8 \pm 1.9$ \\
\hline 24 & $\begin{array}{l}\text { Volume } \dagger \\
\text { Cell no. } \\
\text { Metaphase no. }\end{array}$ & $\begin{array}{c}319.2 \pm 37.3 \\
104.4 \pm 12.9 \\
8.6 \pm 1.8\end{array}$ & $\begin{array}{c}75 \cdot 4 \pm 36 \cdot 2^{* * *} \\
65 \cdot 2 \pm 10 \cdot 6^{*} \\
5 \cdot 2 \pm 1 \cdot 5\end{array}$ & $\begin{array}{r}79.8 \pm 7.9 \\
47.7 \pm 3.4 \\
5.5 \pm 0.9\end{array}$ & $\begin{array}{c}68.9 \pm 5.8 \\
35 \cdot 1 \pm 3 \cdot 0^{* *} \\
4 \cdot 1 \pm 0.8\end{array}$ \\
\hline 48 & $\begin{array}{l}\text { Volume } \dagger \\
\text { Cell no. } \\
\text { Metaphase no. }\end{array}$ & $\begin{array}{c}2510.7 \pm 263.7 \\
248.4 \pm 25.6 \\
15.9 \pm 2.6\end{array}$ & $\begin{array}{c}231 \cdot 2 \pm 279.9^{* * *} \\
217.4 \pm 27 \cdot 1 \\
15 \cdot 0 \pm 2 \cdot 8\end{array}$ & $\begin{array}{r}86.9 \pm 8.0 \\
71.8 \pm 6.7 \\
3.9 \pm 0.6\end{array}$ & $\begin{array}{r}94.7 \pm 4.7 \\
66.9 \pm 4.0 \\
2.9 \pm 0.4\end{array}$ \\
\hline
\end{tabular}

Values are mean \pm s.e.m.

Values significantly different from control value: ${ }^{*} P<0.05 ; * * P<0.01 ; * * P<0.001$.

$\dagger$ Measurement from photographs at a magnification of 200 : volume $=4 / 3 \pi \mathrm{r}^{3}\left(\mathrm{~cm}^{3} \times 10^{-1}\right)$.

\section{Relationship between volume, cell number and number of metaphase plates}

Table 3 shows the regression coefficients between the various measurements. These data give objective values which allow one to calculate an unknown quantity from a given value. For

Table 3. Regression coefficients (b) for the data in Table 2

\begin{tabular}{llcrrc}
\hline & $\begin{array}{c}\text { Dependent } \\
\text { variable }\end{array}$ & $\begin{array}{c}\text { Independent } \\
\text { variable }\end{array}$ & $b\left(\times 10^{-3}\right)$ & s.e. $\left(\times 10^{-3}\right)$ & Significance \\
\hline Rabbit 24 h & CN & V1 & -0.36 & 0.32 & \\
& CN & V2 & 0.10 & 0.01 & $P<0.05$ \\
& MN & CN & 86.53 & 11.92 & $P<0.001$ \\
& V2 & V1 & 536.13 & 825.29 & - \\
\hline Rabbit 48 h & CN & V1 & -1.09 & 0.46 & $P<0.05$ \\
& CN & V2 & 0.23 & 0.08 & $P<0.01$ \\
& CN & V3 & 0.04 & 0.01 & $P<0.001$ \\
& MN & CN & 84.52 & 72.04 & $P<0.001$ \\
& V2 & V1 & 535.69 & 499.16 & $P<0.001$ \\
\hline V3 & V2 & 3846.32 & 689.75 & $P<0.016$ \\
& CN & V1 & 0.05 & 0.16 & - \\
& CN & V2 & 0.12 & 0.05 & $P<0.05$ \\
& MN & CN & 86.59 & 22.73 & $P<0.001$ \\
& V2 & V1 & 1.02 & 0.33 & $P<0.01$ \\
\hline Mouse 48 h & CN & V1 & 0.18 & 0.22 & - \\
& CN & V2 & 0.24 & 0.09 & $P<0.01$ \\
& CN & V3 & 0.25 & 0.09 & $P<0.01$ \\
& MN & CN & 26.25 & 10.06 & $P<0.05$ \\
& V2 & V1 & 395.86 & 271.34 & - \\
& V3 & V2 & 74.82 & 11.13 & - \\
\hline
\end{tabular}

$\mathrm{V} 1=$ volume at $0 \mathrm{~h} ; \mathrm{V} 2=$ volume at $24 \mathrm{~h} ; \mathrm{V} 3=$ volume at $48 \mathrm{~h} ; \mathrm{CN}=$ cell number; $\mathrm{MN}=$ metaphase number. 
example, the number of cells in an embryo can be calculated from the embryo volume. The linear relationships between the single measurements of volume at the 3 times, cell number and metaphase number are generally not very striking. The best relationship exists between cell and metaphase number for the rabbit and mouse embryos, presumably because high cell numbers are caused by high cleavage activity. A relatively poor correlation exists between the volume at 24 or $48 \mathrm{~h}$ and cell number because at these stages the embryos are blastocysts and most of the volume is occupied by the blastocoele rather than cells.

Development in vivo

As shown in Table 4, denuded rabbit embryos were unable to implant. The low control values were believed to be due to technical problems because the proportion of morulae implanting was improved to $70 \%$ in other experiments.

Table 4. Implantations of normal and denuded rabbit embryos transferred at the zygote or morula stage

\begin{tabular}{cccccccc}
\hline & & \multicolumn{2}{c}{ Control embryos } & & \multicolumn{2}{c}{ Denuded embryos } \\
Stage & $\begin{array}{c}\text { No. of } \\
\text { recipients }\end{array}$ & No. transferred & No. implanted & & No. transferred & No. implanted \\
\hline Zygote & 5 & 25 & $5(20 \%)$ & & 29 & 0 \\
Morula & 5 & 25 & $12(50 \%)$ & & 28 & 0 \\
\hline
\end{tabular}

\section{Discussion}

The failure of denuded rabbit embryos to implant confirms the findings of similar experiments (Moore, Adams \& Rowson, 1968), although the lack of a zona pellucida does not prevent implantation of mouse (Tarkowski, 1961; Mintz, 1962) or cattle embryos (J. Hahn, personal communication). Failure to implant seems to be a peculiarity of rabbits. Consequently, this species is not suitable for such experiments if it remains impossible to substitute the zona or mucous layer by artificial envelopes. It is now necessary to investigate the development of denuded cattle embryos in vitro, to check whether they show characteristics similar to those of mouse or rabbit embryos.

This work was supported by the Deutsche Forschungsgemeinschaft. We thank Mrs L. Klügl and $\mathrm{Mr} \mathrm{R}$. Antes for laboratory work and $\mathrm{Mr} \mathrm{L}$. Wörle for statistical analysis.

\section{References}

Konwinski, M., Solter, D. \& Koprowski, H. (1978) Effect of removal of the zona pellucida on subsequent development of mouse blastocysts in vitro. $J$. Reprod. Fert. 54, 137-143.

Maurer, R.R. (1978) Advances in rabbit embryo culture. In Methods in Mammalian Reproduction, p. 265. Ed. J. C. Daniel, Jr. Academic Press, New York.

Mintz, B. (1962) Experimental study of the developing mammalian egg: removal of the zona pellucida. Science, N.Y. 138, 594-595.

Moore, N.W., Adams, C.E. \& Rowson, L.E.A. (1968) Developmental potential of single blastomeres of the rabbit egg. J. Reprod. Fert. 17, 527-531.

Moustafa, L., Hahn, J. \& Roselius, R. (1978) Versuche zur Geschlechtsbestimmung an 6 und 7 Tage alten
Rinderembryonen. Berl. Münch. Tierärztl. Wschr. 91, 236-238.

Nie, N.H. \& Hull, C.H. (1975) SPSS-Statistical Package for Social Sciences. McGraw-Hill Book Company, New York.

Tarkowski, A.K. (1959) Experiments on the development of isolated blastomeres of mouse eggs. Nature, Lond. 184, 1286-1287.

Tarkowski, A.K. (1961) Mouse chimaeras developed from fused eggs. Nature, Lond. 190, 857-860.

Tarkowski, A.K. (1966) An air-drying method for chromosome preparations from mouse eggs. Cytogenetics 5, 394-400. 